\title{
LORD DENNING AND MARGARET THATCHER, LAW AND SOCIETY
}

\author{
Simon Lee
}

\section{HEROES OR VILLAINS?}

"Lord Denning is the best-known and best-loved judge in the whole of our history." That was the opening of Lord Bingham's address at the service of thanksgiving for the life of Lord Denning, the former Master of the Rolls, in Westminster Abbey in 1999. Lord Bingham was well-placed to judge. He himself held the offices of Master of the Rolls, Lord Chief Justice and Senior Law Lord. He is an accomplished historian. He ascribed Lord Denning's renown and reputation to his unique warmth, his popular touch and his longevity. Tom Denning was born in the Victorian era, in 1899, and lived a few weeks beyond his $100^{\text {th }}$ birthday in 1999 . He only retired at the age of 82 and then reluctantly.

When Baroness Thatcher died in 2013, David Cameron as Prime Minister opened the tributes in the House of Commons:

"In the long history of this Parliament, Margaret Thatcher was our first - and so far only - woman Prime Minister. She won three elections in a row, serving this country for a longer continuous period than any Prime Minister for more than one hundred and fifty years ... As Tony Blair rightly said this week, Margaret Thatcher was one of the very few leaders who changed not only the political landscape of their own country, but the rest of the world too. Above all she believed to the core of her being that Britain stood for something in the world - for democracy, for the rule of law, for right over might. Today, in different corners of the world, there are millions of people

\footnotetext{
* Emeritus Professor of Jurisprudence, Queen's University Belfast. This article derives from a public lecture, 'Lord Denning, Margaret Thatcher \& the Rule of Law', given at the University of Buckingham on 16 July 2013. I am grateful to Professor Susan Edwards for the invitation, to those who attended for entering into the spirit of the occasion and for their comments afterwards and to James Lee for comments on drafts. Responsibility for the content is mine alone.

${ }^{1}$ T Bingham, The Business of Judging (OUP 2000) 409.
} 


\section{LORD DENNING \& MARGARET THATCHER, LAW \& SOCIETY}

who know that they owe their freedom, in part, to Margaret Thatcher."

On the other hand, there are less flattering ways of looking at the legacies of Lord Denning and Baroness Thatcher. ${ }^{3}$ The Independent newspaper in Ireland had as the headline to its obituary of Lord Denning, "'Appalling vista" judge dies at 100", "while a sense of the hold of celebrities in modern forms of media is given by the comedian Russell Brand's verdict on the death of Margaret Thatcher in the Huffington Post: "If you behave like there's no such thing as society, in the end there isn't ... all of us that grew up under Thatcher were taught that it is good to be selfish, that other people's pain is not your problem, that pain is in fact a weakness and suffering is deserved and shameful." Examples could be multiplied, from the popular press and popular comedians through to Professors John Griffith ${ }^{6}$ and Ronald Dworkin ${ }^{7}$ as academic critics. Part of the reason for this article is the sense that the headlines and the comedians are carrying more sway than senior judges or politicians when it comes to interpretations of the views and records of Lord Denning and Baroness Thatcher. This matters because how are students and the wider community to balance these competing interpretations unless universities encourage an interest in the lives of public figures and in fairness when it comes to judging them?

Students from diverse backgrounds might also find something of their own challenges and opportunities in the stories of Lord Denning and Baroness Thatcher. Both rose to high office from humble beginnings above family shops. Neither went to a fee-paying school. Both became barristers after first

2 http://www.theguardian.com/politics/2013/apr/10/margaret-thatcher-tributes-davidcameron-speech

${ }^{3}$ I am conscious that the title of the lecture and now the article gives Tom Denning his title of Lord but renders Baroness Thatcher as Margaret. I have chosen the title by which Lord Denning was known during his time as Master of the Rolls. The equivalent for Margaret Thatcher as Prime Minister would have been Mrs Thatcher but she later became a Baroness. Since she was not Lady Thatcher or Baroness Thatcher when in office, I have chosen 'Margaret Thatcher'. No disrespect is intended. Where it seems more appropriate to refer to them in different ways, eg by surnames alone or as Tom Denning or as Baroness Thatcher, I have done so.

4 Independent http://www.independent.ie/irish-news/appalling-vista-judge-dies-at100-26155585.html

5 Huffington Post http://www.huffingtonpost.com/russell-brand/margaret-thatcherour-unm_b_3046390.html

6 J Griffith, The Politics of the Judiciary, http://www.lrb.co.uk/v12/n20/johngriffith/that-man-griffith

${ }^{7}$ R Dworkin, http://www.nybooks.com/articles/archives/1988/oct/27/the-new-england /?pagination=false 
studying a different subject at university, Mathematics and Chemistry respectively. Neither found it easy at first to make their way at the Bar. Today's students of law and politics could benefit from a balanced understanding of the lives and beliefs of such a leading judge and such a leading politician.

In returning to my attempt twenty-five years ago in Judging Judges ${ }^{8}$ to counter the simplistic idea that members of the establishment get there through privilege and decide everything on the basis of class bias, I would like now to counter more specifically the notion that we can reduce the legacies of leading figures in our law and politics to a phrase or two, plucked out of context. The phrases I have in mind are Lord Denning's appalling reference to "appalling vista" in a miscarriage of justice case and Margaret Thatcher's infamous declaration that "there is no such thing as society". There is much more to Lord Denning and Baroness Thatcher than these comments.

This is not to excuse the mistakes of Lord Denning or Baroness Thatcher but to insist that one view of one aspect of their careers is not a rounded picture of long lives of public service. The same applies to judges and politicians of other eras and applies across the spectrum of judicial styles or party political affiliations. For example, the reputation of Tony Blair, another barrister who also won three general elections, is nowadays often dismissed on the basis of the Iraq war. When I wrote about him in Uneasy Ethics, ${ }^{9}$ published in 2003 but drafted in 2002, before we were aware of the issues around dossiers on weapons of mass destruction, it was possible to be heard if offering an analysis of his 'Third Way'. While critical of it, my thesis was that it appealed to him in some respects as an application in politics of the method adopted in his tutorials as a law student. There are pluses and minuses to that in tutorials, in law and in politics - but ten years on, the sound of any balanced analysis is in danger of being drowned out by the clamour in the public square against Mr Blair's support for the 'war on terror'.

On a future occasion, I intend to analyse the strengths and weaknesses of Lord Denning's and Margaret Thatcher's interpretations of the rule of law, with particular reference to national security and with some attention to insights of the philosopher Anthony Quinton to our assessment of such figures. Lord Quinton, ennobled on the recommendation of Margaret Thatcher has pointed out some confusion and overlap in discussions of character and personality: "Castlereagh, perhaps, had character without personality;

\footnotetext{
${ }^{8} \mathrm{~S}$ Lee, Judging Judges (Faber 1988). I am conscious that in writing about other academics in such books and in book reviews of my own, before, during and after my time as Book Review Editor of the Law Quarterly Review, I could be accused of similar faults in selective citation of opposing views, as indeed could my critics.

${ }^{9}$ S Lee, Uneasy Ethics (first published Pimlico 2003; Random House ebook 2011).
} 
Alcibiades personality without character." ${ }^{10}$ Quinton has also raised important questions about intellectual biography and autobiography. Lord Denning, towards the end of his career, wrote a series of books telling his own story in his own inimitable way. We are more accustomed to autobiography from former prime ministers but we have come to expect such volumes to be dull and self-serving. Since Lord Denning was a past-master of narrative, it is not surprising that his spate of books was more engaging. Of course, any autobiography is likely to be self-serving but Quinton argues there can be a special value in an intellectual autobiography as the "actual process of thought ... is known only to the thinker himself, so far as his memory is reliable". ${ }^{11}$ What Quinton is looking for are "particular moments of enlightenment, the detailed procedure of working at a problem, the actual experienced effects of influential people and books". ${ }^{12}$ Margaret Thatcher not only wrote her own memoirs $^{13}$ and is now the subject of various biographies ${ }^{14}$ but she was interviewed time and again, especially as the UK's first female Prime Minister and reaching back to the days when it was a novelty for the media that a woman was standing as a parliamentary candidate. A consistent narrative emerges from exploring the archive of these transcripts and all her speeches held by her foundation. ${ }^{15}$ This material tells a story about society and about what Margaret Thatcher believed had influenced the development of her thinking.

In law and in other disciplines, there is much scholarship around what it is to 'interpret' the past, about what it means to claim that something is 'true' or 'authentic'. Historians of education, for example, have reflected on hermeneutics and the reliability of memory in evaluating the methodology of a major oral history project interviewing hundreds of teachers. ${ }^{16}$ So I am not claiming that Lord Denning and Baroness Thatcher should be given the last word on their own achievements. My aim is instead to find a way of presenting more than the nine of their words which are in danger of blocking an appreciation of their lifetimes of experience of law, politics and society.

\footnotetext{
${ }^{10}$ A Quinton, Thoughts and Thinkers (Duckworth 1982) 21.

11 Ibid, 35.

12 Ibid, 35-6.

${ }^{13}$ M Thatcher, The Path to Power (HarperCollins 1995); The Downing Street Years (HarperCollins 1993).

14 The authorised biography, part one, is C Moore, Margaret Thatcher, from Grantham to the Falklands (Allen Lane 2013).

${ }^{15}$ The Margaret Thatcher Foundation http://www.margaretthatcher.org/

${ }^{16}$ P Gardner, Hermeneutics, History and Memory (Routledge 2010); P Gardner, 'Oral History in Education: Teacher's Memory and Teachers' History' (2003) 32 History of Education 175; and P Cunningham and P Gardner, Becoming Teachers; Texts and Testimonies: 1907-1950 (Woburn 2004).
} 
They are especially intriguing leaders because they are judged by some to have been conservative and by others to have been radical.

For Lord Denning, then, the aim of this article is to identify, especially but not exclusively for the benefit of law students born after he had retired, why a rounded view of his life and of his progress in the law is of some significance.

For Baroness Thatcher, the aim is to identify, especially but not exclusively for the benefit of students of politics born after she had resigned as Prime Minister, exactly what she said and meant about 'society'.

\section{LORD DENNING: THE MORAL OF HIS STORY}

"It was bluebell time in Kent."17 Many a student might vote for that sentence from Hinz $v$ Berry as the most memorable of the many distinctive openings in judgments by Lord Denning, during his twenty year tenure as Master of the Rolls. As I was born in Kent and as the bus I took to school each day came from Bluebell Hill, Hinz $v$ Berry is in my personal top two, the other being, as a village cricketer, Miller $v$ Jackson. ${ }^{18}$

Even when a phrase is repeated so often, it is possible to be mistaken about exactly where it comes in a judgment or why it was there at all. "It was bluebell time in Kent" was not, in fact, the very first sentence of Hinz $v$ Berry. That was simply, "It happened on 19 April, 1964." It is the second sentence which told us that it was bluebell time in Kent. Of course, it hardly matters whether this was the first or second sentence but if anyone thinks they have remembered it as if it were the first, then that in itself is a tiny example of the value of revisiting our recollections and understanding of the content and context of any comment in law or politics. There are other ways of learning how easy it is to forget. In refreshing my understanding of Lord Denning's successors as Master of the Rolls, from Lord Donaldson, appointed by Margaret Thatcher's government, through to the current incumbent, Lord Dyson, it was only when I saw towards the end of what I was increasingly deeming to be an especially fair-minded obituary of Lord Donaldson that the author had been in court for a particular case, where I knew I too had been watching the drama unfold, that it dawned on me that I had written that obituary. ${ }^{19}$

Once every quarter of a century or so, it is good to take stock, not merely to wallow in nostalgia at the lighter-hearted end, or beginning, of judgments,

\footnotetext{
${ }^{17}$ Hinz v Berry [1970] 2 QB 40.

${ }^{18}$ Miller v Jackson [1977] QB 966: "In summertime, village cricket is the delight of everyone."

${ }^{19}$ Simon Lee, The Guardian, 3 September 2005,

http://www.guardian.co.uk/news/2005/sep/03/guardianobituaries.obituaries.
} 
but to remind ourselves of the origins of a senior judge or politician and of the influences on their thoughts and actions. The "nightmare, ${ }^{20}$ explanation of judicial or political decision-making is that people in power decide in a selfserving way, often because of their class or gender or race or education or a combination of such elements in their background. This is not much of a theory of adjudication, it seems to me, and it does not sit well with the theory of advocacy that often draws students into law, the idea (whether seen in films or television or on stage or read about in fiction or even sometimes in fact) or the "noble dream" ${ }^{21}$ that the student will secure justice through the quality of their argument. For, if that is so, judicial bias could not be decisive. Yet judges are accused of acting like politicians. One of the reasons why I have decided to consider together a leading judge and a prime minister is because I have come to think that there is a danger in the apartheid or voluntary segregation whereby law students and researchers write about judges while politics students and researchers write about elected representatives. In a modern democracy, it is helpful to compare and contrast the two elements, to see if they complement and challenge one another as is appropriate, which will not always be the same in different eras. This overlap between law and politics has been a long-standing interest of mine. Along the way, I have by no means always agreed with Lord Denning or Baroness Thatcher. The very first article I wrote on law was critical of Lord Denning's inconsistency, as I saw it, in his approach to the mandate of the central and local governments in the Tameside and GLC cases of the mid-1970s and early 1980s. ${ }^{22}$ I quoted one letter-writer to a national newspaper (he wrote at least two that were published) who suggested renaming London as Denningrad if Ken Livingstone could not reduce fares on London transport in accordance with the Labour manifesto. His other way of putting it was to ask if we were to have the single name Denning on our voting slips. ${ }^{23}$

Many of those who resented Lord Denning in such cases were pleased when he had earlier championed the deserted wife's equity in a series of cases which upheld equal opportunity in the late 1950s and early 1960s, when parliament had failed to act. ${ }^{24}$ If Lord Denning decided against Labour just

${ }^{20}$ Judging Judges (n 8), ch 4, 33.

${ }^{21}$ Ibid ch 3 .

${ }^{22}$ S Lee, 'Mandate and Manifesto' (1983-4) 33 King's Counsel 39.

${ }^{23}$ Ibid at 40, quoting George Stern's letters to The Guardian and The Times published on 13 November 1981.

${ }^{24}$ See eg a lecture by Lord Neuberger, a later Master of the Rolls, for a pithy summary of Lord Denning's attempt to 'sire' or be 'midwife' to the deserted wife's equity, an attractive baby that was 'decisively murdered' on appeal by the House of Lords but which was brought back to life by statute: http://www.judiciary.gov.uk/Resources/JCO/Documents/Speeches/mr-speech-hongkong-lecture-12102010.pdf 
because he was conservative, did that mean he would decide against the woman in cases of a broken marriage or other relationship because he was a man? That was clearly not the case. Nor did Lord Denning accept the premise, that he was a conservative. When asked by the barrister and writer, John Mortimer QC, in an interview for The Sunday Times, reprinted in his book, In Character, ${ }^{25}$ if he was a conservative with a small 'c' or a liberal with a small ' 1 ', Lord Denning could not have been clearer, having already declared that he had never voted for a political party:

"Oh, I'm not conservative. People have said the Court of Appeal's very conservative. They forget that when Donaldson put the three dockers in prison in the Industrial Court, we let them out. Well, we'd been told there was the danger of a general strike. Most lawyers are conservative. That's what's wrong with them. I would have to say that I'm on the liberal, or the progressive side. I believe in equal opportunity for everybody, and as an old grammar-school boy, I believe in independent schools. I believe in an elite of excellence, certainly not in an elite of the upper class. I would be against that." 26

The arrogance of any simplistic view that judges are conservative or Conservative is hardly likely to be undermined by a clear statement from the judge that he was not conservative, let alone Conservative, nor by his repeated assurance that he had never voted for any political party in any election. Critics might see a system in which the judges are against them and conclude that is because of the judges' politics, not theirs, and not because parliament had passed a statute addressing the matter. They might prefer to believe it was because of the judges' privileged backgrounds. I have written about this as an absurd 'Tory Benn' thesis, that because judges tend to be old, white, male, public school and Oxbridge (just like the left-wing politician, Tony Benn), they automatically think in a conservative way (just unlike Tony Benn). ${ }^{27}$ The conclusion does not follow but in the case of Tom Denning the premise is wrong and, in a different meaning of the word, premises, this is a point which links to the life story also of Margaret Thatcher.

For, as noted above, Tom Denning did not come from a privileged background. He was born over his father's draper's shop. ${ }^{28}$ He went to a state school and went to war before he qualified at the bar. It is evident from this that I am not denying that our backgrounds influence us to some degree. On the contrary, that is one reason why biographies can be of value. But a single

\footnotetext{
25 J Mortimer, In Character (Penguin 1983) 9.

${ }^{26}$ Ibid, 13.

${ }^{27}$ Judging Judges (n 8) 33.

${ }^{28}$ T Denning, The Family Story (Hamlyn 1982) 16-18.
} 


\section{LORD DENNING \& MARGARET THATCHER, LAW \& SOCIETY}

factor, such as our gender or school or class, is not in my opinion the whole or even the primary explanation of how we decide everything in later life, especially if we are in a constitutional role as judges which requires us to listen to the arguments, to the views of others, and to articulate our reasons, to have them subjected to criticism in the courts, in parliament and in the court of popular opinion, including through trial by media. If we think that we would always decide for the union or for the woman or for the big business or the little shopkeeper, even that does not show it is what judges or politicians do. It could be that it shows we would not be the best of judges or politicians.

Far from privilege explaining how Lord Denning decided as a judge, my contention is that it was his lack of privilege and the consequent struggle he had to become a lawyer which influenced positively his generosity of spirit to students, new lawyers and good causes as well as his renowned courtesy to almost all litigants. I do not deny that he fell short of his own standards in the miscarriage of justice cases. Nor do I excuse that. His experiences in earlier conflicts might have some bearing on his inability to imagine that what he characterised as an "appalling vista" had truly happened but others of his generation, including retired judges ${ }^{29}$ were able to rise above that and campaign for the righting of wrongs in those miscarriage of justice cases. So my point is that we can learn from his experiences in earlier life, notwithstanding the disappointing comments in and out of court which led to his retirement. In particular, today's students might find some encouragement from an experience which they share with Lord Denning but which was a burden from which my generation was spared. Students in an era of high fees which they have to pay or repay are in that respect closer to the position of a Tom Denning ninety or more years ago than to their own teachers.

Every penny counted for Tom Denning to be able to survive as a poor scholar at university. He was always grateful for scholarships and advice and he later helped good causes in turn. He was especially thankful that the President of his Oxford college, Magdalen, Sir Herbert Warren, took a personal interest in finding the means for him to persist in his studies and to find his way afterwards. ${ }^{30}$ Denning was well aware that Warren was widely regarded as a snob. Even a fellow Magdalen student, the Prince of Wales, later known as Edward VII and then as the Duke of Windsor, himself no slouch when it came to being snobbish, saw some absurdities in Warren. ${ }^{31}$

\footnotetext{
${ }^{29}$ Lords Devlin and Scarman were prominent in the campaigns to right the wrongs of miscarriages of justice.

${ }^{30}$ Ibid 34.

${ }^{31}$ Duke of Windsor, A King's Story (Cassell 195) 94: “It was generally suspected that he was obsessed with the idea of filling Magdalen with titled undergraduates; hence, whenever he beamed upon me, I was never quite certain whether it was with a teacher's benevolence or from a collector's secret fascination with a coveted trophy."
} 
With this reputation, Warren might have been expected to look down on a state school educated student like Tom Denning who retained the burr of his Hampshire accent. Yet that was not Denning's experience of Warren who helped him time and again. When Denning returned to Oxford after the First World War and after his first degree in Maths, Warren steered him towards studying for an accelerated second degree, this time in Law, and went to London to seek a further scholarship for Denning:

'He was decried by some as being a 'snob' ... But I would refute this disparagement. The President was very good to me. He helped me at every turn." 32

Tom Denning was given a viva days after the Law of Property Act was passed in 1922 (as a precursor to the wider reforms of 1925) and impressed the examiner Professor Cheshire with his knowledge of the latest developments. ${ }^{33}$ When Cheshire's son, Leonard, having won the Victoria Cross for outstanding bravery in the Second World War as a Dambuster pilot and having witnessed the dropping of the atomic bombs, started homes for those with severe disabilities, the other trustees were his father and Tom Denning, who chaired the trust. ${ }^{34}$

Tom Denning also needed help to survive at the Bar:

"I too was briefless for a time. I used to devil for the busy juniors - in our chambers and outside. That is, I used to look up cases, to draft pleadings or opinions - all without payment. Save that Mr D N Pritt did give me a most welcome cheque sometimes. He had one of the biggest commercial practices of the day: and also in the Privy Council. He helped me much. When he was a silk he gave me my 'red bag'. A new barrister has only a blue bag. If he does well in a particular case, the silk may give him a red bag." 35

Lord Denning does not point out anything else about this character and the casual reader will just absorb that he was helped by a successful commercial barrister. Indeed, I am not aware of anybody else pursuing a study of Mr D N Pritt in this context. There is a story though to this patron of the young Tom Denning which illustrates the huge range of political opinion at the Bar between the wars and the way in which such differences did not preclude generosity to one another. Denis Nowell Pritt became a QC and, more briefly,

${ }^{32}$ Denning (n 28) 34.

${ }^{33}$ Ibid, 38.

${ }^{34}$ A Boyle, No Passing Glory (Collins 1955) 362; Denning (n 28) 241.

${ }^{35}$ Denning, ibid 94. 
a Labour MP. He was a prolific writer of tracts, especially in support of the USSR. ${ }^{36}$ D N Pritt campaigned for civil liberties at home but has been accused by the left-wing journalist and author Nick Cohen in What's Left? of being "on the wrong side of every great question of the mid-twentieth century". ${ }^{37}$ Pritt could be described as a "fellow-traveller", ${ }^{38}$ as in all likelihood the most pro-Soviet barrister in our history. In 1954, on the eve of the $75^{\text {th }}$ anniversary of Stalin's birth and in the year after his death, Pritt was one of nine recipients of the annual International Stalin Peace Prize, later renamed in honour of Lenin. ${ }^{39}$ Lord Denning remembers him, however, simply as a generous senior colleague who made his own career possible. He was far more privileged than Lord Denning, far richer and far more left-wing. He must have seen young Tom Denning's talent. In paying for his help, he enabled the poor young barrister to survive at the Bar.

A reader of Lord Denning's book about his own family will appreciate that when it comes to understanding Lord Denning's approach to questions of law, order and national security, it is worthwhile knowing what Lord Denning did in, and how he was affected by, the wars. In the First World War, two of his brothers were killed. A sister was not allowed to fight, one brother was too young and so was Tom initially. He was then refused on medical grounds but characteristically appealed and eventually was able to go to the front, leaving his studies behind to fight for victory. He had enlisted with the Royal Engineers and worked with Welsh miners on construction at the coal-face, so to speak, of the war. Like many others, he was stricken with influenza towards the end of the war but lived to be a part of the trio of surviving brothers who became an admiral, a general and a judge. ${ }^{40}$

A certain robust approach to national security is likely for someone with this experience of the First World War. In the General Strike in the 1920s, Tom Denning acted as a special constable. ${ }^{41}$ In the Second World War, he was too old to enlist in the military but acted as the lawyer in the North-East dealing with such issues as detention without trial of people suspected of being sympathetic to the enemy as legal adviser to the regional commissioner. "We detained people, without trial, on suspicion that they were a danger."

\footnotetext{
${ }^{36}$ See eg N Pritt, The Zinoviev Trial (1936); Light on Moscow (1939); The USSR Our Ally (1941); The Truth about the USSR (1951); Russia is for Peace (1951).

${ }^{37}$ N Cohen, What's Left? (Harper 2007).

${ }^{38}$ D Caute, Fellow-Travellers: the Intellectual Friends of Communism (Yale 1988) 167.

${ }^{39}$ Cohen (n 39) but relevant passage reproduced at http://nickcohen.net/2009/03/02/eric-hobsbawm-and-the-hitler-stalin-pact/

${ }^{40}$ Denning (n 28) 106 and 123.

${ }^{41}$ Ibid, 79.

${ }^{42}$ Ibid, 130.
} 
He referred in the third person in his famous Hamlyn lectures on freedom under the law ${ }^{43}$ in 1947 to the case of a vicar in Leeds suspected of being a Nazi-sympathiser. Lord Denning had no hesitation in interning him without any evidence. This kind of detention without trial was allowed in a different case during the war by the House of Lords in Liversidge $v$ Anderson ${ }^{44}$ but Denning later praised the famous dissent of Lord Atkin. ${ }^{45}$ Counsel for Liversidge was Tom Denning's lifeline as a young barrister, D N Pritt KC. Nor in peacetime did Tom Denning find it difficult as a judge to sentence a convicted murderer to the death penalty. As he told John Mortimer, "Didn't worry me in the least. I've done it lots of times.",46

Lord Denning was too robust, too rash and spoke too loosely in 1980 when the Birmingham Six were suing West Midlands police for beatings in police custody. This was seen by Lord Denning as an attempt to have a rehearing of their case through a side door. There already had been an appeal. This attempt to show that they were the victims of a gross miscarriage of justice, as indeed they were, was struck out by Court of Appeal. If they had won it would have revealed perjury and widespread malpractice in their treatment in custody by the police. "That, said Lord Denning, is such an appalling vista that every sensible person in the land would say: it cannot be right that these actions can go any further". ${ }^{47}$ It was indeed an "appalling vista' but it was true and what was needed was to give every chance to show it was true and to take steps both to minimise the chances of a repetition and to maximise the opportunities for review where there were thought to be other miscarriages of justice. Nothing in this article is meant to excuse this error of judgment by Lord Denning. My point is rather that it does not tell the whole story of our greatest judge and that we must strive for a balanced view. At the end of the decade in which he said this, a leading nationalist MP, Seamus Mallon, of the SDLP was asking a question of Margaret Thatcher in the House of Commons on 16 March 1989. Raising the issue of the obstruction of the Stalker inquiry, he prayed in aid Lord Denning:

"Does the Prime Minister agree with the maxim enunciated by Lord Denning: 'Be you never so high, the law is above you'? If she does,

\footnotetext{
${ }^{43}$ See Ibid, 130.

44 [1942] AC 206.

45 At 244, praised in Denning (n 28) 130 as "after my own heart".

${ }^{46}$ Ibid.

${ }^{47}$ McIlkenny v Chief Constable of West Midlands [1980] 1 QB 283. This is not the only reason why Lord Denning was under pressure to retire. He wrote and spoke out of turn on a related and an unrelated matter (impugning black jurors, which I noted in my chapter on Lord Denning in Judging Judges (n 8) but it is the "appalling vista" quote which has been used so often in the subsequent twenty-five years).
} 
how does she justify the squalid and murky attempts to hide the truth about the Stalker affair? Has she any appreciation whatever of the damage that has been done to confidence in the police, in the process of justice and, above all, in a Government who have shown how low standards can apply in high places?"

Leaving to one side the detail of that matter, it is striking that Seamus Mallon finds it natural and telling to refer to Lord Denning (who was quoting Dr Thomas Fuller from the eighteenth century). ${ }^{49}$ It would be good, almost a quarter of a century later, to return to that practice of remembering Lord Denning as someone who captured the imagination by the way he framed this insistence on the principle of the rule of law, rather than to write him out of our legal history for falling short of that standard in the context of a miscarriage of justice.

There is a further tragic irony in Lord Denning's failure to allow for the possibility that the facts in a miscarriage of justice might not be as the police had presented them to the courts. For it is his ability to narrate the facts of a case in such a compelling fashion which was the hallmark of the openings of his judgments. The bluebells in Kent illustrate Lord Denning's remarkable facility for distilling the facts of a case and putting in some colour in what was often seen as a dull exercise. Some students think the reason why this beautiful bluebell sentence is famous is for its irrelevance to a tragic case. Yet it is more the contrast and the evocative way in which Lord Denning sets the scene and grabs attention that has made the bluebells and the judge so wellknown. The bluebells were relevant to the story. Mrs Hinz was pregnant with her fifth child and was foster-mother to four further children. On the way home from an outing, she took her three year-old child, Stephanie, across the road to pick bluebells while her husband and the other seven children were getting ready in a lay-by to have a picnic tea. Another motorist had a burst tyre and ploughed into the Hinz family, injuring several children and killing Mr Hinz. The question for the Court of Appeal was whether she was entitled to the $£ 4,000$ damages awarded by a judge for her nervous shock at witnessing the death of her husband. She was. ${ }^{50}$ As Lord Bingham said towards the end of his great address in Westminster Abbey, Lord Denning "saw the law not as a code of rules, but as a collection of human stories, each

\footnotetext{
${ }^{48} \mathrm{http} / /$ www.margaretthatcher.org/document/107604.

${ }^{49}$ Lord Bingham traces the quotation in The Rule of Law (Penguin 2010) in $\mathrm{n} 8$ to ch 1 at 175 although it is sometimes rendered as "ever" rather than "never".

${ }^{50}$ In Judging Judges (n 8) Ch 3, 20-32, I discuss the later nervous shock case of McLoughlin $v$ O'Brian [1983] 1 AC 410, which was chosen by R Dworkin to illustrate his theory of adjudication in Law's Empire (Belknap Press 1986).
} 
with a moral ...". ${ }^{51}$ My own interest in leading judges is stimulated by not seeing them as a collection of rulings, from which we take the worst as if that sums them up, but as characters and personalities in each chapter of whose lives there might be a moral worth pondering.

\section{MARGARET THATCHER: WHAT SHE SAID AND MEANT ABOUT SOCIETY}

That sentence by Lord Bingham continues with a reference to society and then to social harmony, that Lord Denning saw the law "... not as a fetter, but as a source of freedom; not as an unwelcome but inescapable response to the ills of society, but as a means of providing that justice upon which good government and social harmony fundamentally depend." 52 Those who think that Margaret Thatcher did not believe in society will not know how she would be able to make sense of such an insight. My view is that she would have been able to have endorsed it and that she shared much of Lord Denning's and Lord Bingham's thinking on the importance of the rule of law in society.

In the wake of Baroness Thatcher's death this year, there have been many accounts of her life so there is little need to rehearse the story in her case, except to mention how the law came into her life. It has already been noted here that she came from shop-keeping stock, in her case a grocer's cornershop, and that she studied Chemistry at Oxford. Margaret Thatcher took her first bar exams in May 1952, gave birth to twins in August 1953, passed bar finals on 1 December 1953, was called to the bar in February 1954 in alphabetical order between two people who went on to become MPs, Dick Taverne and Jeremy Thorpe. ${ }^{53}$ She was a pupil with Fred (later Lord Justice) Lawton in whose chambers were other rising stars. Airey Neave, war hero and escaper from Colditz, later a Conservative MP and her campaign manager for the leadership, was blown up by the IRA in the precincts of Westminster ahead of the 1979 General Election which Margaret Thatcher went on to win. Robin Day was later a particularly acute questioner of her and other politicians as a television interviewer. Although Margaret Thatcher did not complain about it, there seems to have been bias against a mother at the bar in those days, so it was not an easy time but she later said that she valued learning how to draft, which helped her as a minister dealing with civil servants, and learning about the importance of the rule of law, which helped her evolving political philosophy.

\footnotetext{
${ }^{51}$ Bingham (n 49) 412.

${ }^{52}$ Ibid 412-3.

${ }^{53}$ C Moore (n 14)125-6.
} 


\section{LORD DENNING \& MARGARET THATCHER, LAW \& SOCIETY}

What was Margaret Thatcher doing in April 1964 when the facts occurred which gave rise to Hinz v Berry? Politicians were preparing for the 1964 general election. When she died earlier this year, a Jewish magazine in her constituency asked for memories. In the early summer of 1964, one correspondent recalled, ${ }^{54}$ he and his wife went to Israel for a few days. He was the leader of the Liberal party on Finchley council. There was only one person in the swimming pool at their hotel in Eilat. She recognised them, swam towards them and engaged him in conversation from the pool. That was, of course, their MP, Margaret Thatcher. So she was not preparing too hard for the election, then. This story emerged too late for Charles Moore's new biography ${ }^{55}$ but he too likes the game of spotting what everyday activities Margaret Thatcher was up to on famous dates, such as when John F Kennedy was assassinated the previous year. She was at a Rotary club event. For much of that year, 1963, Lord Denning was famously involved in questioning witnesses and writing his Report into the Profumo affair. ${ }^{56}$

Even before illness affected her memory, Margaret Thatcher was not always accurate in dating her own recollections. She told Geoffrey Smith, ${ }^{57}$ for example, that she distinctly remembered in 1959 the case of Rookes $v$ Barnard, ${ }^{58}$ but it was in fact in 1964. Still, her reason for mentioning it is significant. She was appalled that the government had not protected the pilot who did not want to be in a closed shop, required by his employer to join a trade union. She thought that was an outrage.

What was Margaret Thatcher doing when Lord Denning was giving his judgment in the case of Hinz $v$ Berry? He was speaking, immediately on conclusion of the argument, in January 1970. It was not Lord Denning's fault that it took almost six years for Mrs Hinz to have her case resolved. There are still concerns today about the length of time, on the one hand, that such cases can take, and the sense, on the other, that there is too much of a compensation culture. At the end of January 1970, Margaret Thatcher and the rest of the shadow cabinet were in the Selsdon Park hotel laying the basis for the Conservative manifesto with which they won the 1970 general election. ${ }^{59}$ Politicians spend a lot of time preparing for elections. It might seem that their task is so removed from the lot of judges that it is unprofitable to compare

\footnotetext{
${ }^{54}$ Alan Cohen, The Norrice Leader, June/July 2013 p 8. http://www.hgss.org.uk/home/Norrice\%20Leader/20130607.pdf

${ }^{55} \mathrm{C}$ Moore (n 14).

56 Denning, The Denning Report: The Profumo Affair (Pimlico 1992); this is a surprising re-issue of the official report with a new introduction by Lord Denning.

${ }^{57} \mathrm{http} / / /$ www.margaretthatcher.org/document/109324.

${ }^{58}$ Rookes v Barnard [1964] AC 1129.

$59 \mathrm{http} / /$ www.margaretthatcher.org/document/109512 \& transcripts of subsequent sessions.
} 
them. On the other hand, there is some overlap in their roles and in their talents. Both professions at their highest levels require, or in their era required, wordsmiths or at least the ability to sift and draw on the arguments of others to articulate the reasoning behind their decisions.

This means that both a politician of Baroness Thatcher's calibre and a judge of Lord Denning's leave a legacy of millions of words. Yet even though Lord Denning was our best known judge and Margaret Thatcher perhaps our best known politician of the twentieth century, how well do we really know them and how many of those words do we allow them in our estimation of their achievements? If we are partial, unfair or mistaken in our judgments of the best known figures in law and politics, how wrong might we be in our assessment of others? ${ }^{60}$

In some spheres, a lifetime is reduced to a single image or moment. In others, it can be a single phrase. Margaret Thatcher is associated with seven words: "there is no such thing as society". Lord Denning is associated with two words: "appalling vista". Yet each was responsible for some of the most evocative statements of our politics and our law in the twentieth century. Why do their critics think it is fair to focus on these particular words? The answer they might give is that these comments reflect the public figures' true views, that they reveal something significant about the characters and assumptions of these privileged people. It could be, however, that the critics are seizing on an unrepresentative sample for their own purposes. The common law tradition encourages us instead to anticipate the best possible interpretation of our opponents' positions before countering them. The structure of legal argument in such systems is intended to ensure that decision-makers have been exposed to the best arguments on each side of a two party dispute. More recently, we have taken to third party interventions when there is a public interest beyond the main litigants.

In contrast, almost anything goes in our media and our politics, although there is an etiquette policed by the Speaker in the House of Commons. A close cousin of the Scholastic approach to scholarship is a Catholic catechism's injunction to strive to avoid the non-identical twin sins of calumny and detraction. Calumny ${ }^{61}$ is when you tell an untruth about someone

\footnotetext{
${ }^{60}$ See eg S Lee and P Stanford, Believing Bishops (Faber 1990) through to Uneasy Ethics (n 9) \& S Lee, The Z to A of Oxford Sport (AudioGo 2012). A work in progress with Dr Richard Turnbull, whose Shaftesbury: the Great Reformer (Lion 2010) is a good illustration of this, explores the religious inspiration of nineteenth and twentieth century campaigners for social reform and founders of charities.

61 Catechism of the Catholic Church (Veritas, 1994) \#2477: Calumny is where someone "by remarks contrary to the truth, harms the reputation of others and gives occasions for false judgments concerning them".
} 
which undermines their reputation. Detraction ${ }^{62}$ is when you tell the truth about someone which undermines their reputation and when there was no need to do so. In an era of widespread vitriol on-line, the practice of calumny and detraction might seem to be beyond redemption, even if the sinners are not. But trying to avoid calumny and detraction is relevant to judicial and political biography. In what follows, I seek to illustrate how the fact that Margaret Thatcher said there is no such thing as society does not mean it is fair for her detractors to pray it in aid as a summary of her position.

You might imagine that it was David Cameron, the current Prime Minister, who told a Conservative Party Conference that, "In its first seventeen months this Government have laid the foundations for recovery" 63 or you might be unsure whether he is joking or has picked up the wrong speech. If he were to say of the Deputy Prime Minister that he is "very fortunate in having a marvellous deputy who is wonderful in all places at all times in all things", 64 you would know that someone had given him Margaret Thatcher's speech from the 1980 conference. In that speech, she said a great deal about 'society' even though she was quoted, seven years later, as declaring that society does not exist.

The first point she made about society at the 1980 conference was that, "Inflation destroys nations and societies as surely as invading armies do." Next, Margaret Thatcher linked the economy and society, while distancing both from a big state:

"Without a healthy economy we cannot have a healthy society. Without a healthy society the economy will not stay healthy for long. But it is not the State that creates a healthy society. When the State grows too powerful people feel that they count for less and less. The State drains society, not only of its wealth but of initiative, of energy, the will to improve and innovate as well as to preserve what is best." 66

Some of us might disagree with that last claim as being too harsh on the positive aspects of the State but there is no doubt from this that Margaret Thatcher believed in society and could see, in 1980, that if there were no such thing as society, there would be chaos: "People yearn to be able to rely on

${ }^{62}$ Ibid. Detraction is where someone "without objectively valid reason, discloses another's faults and failings to persons who did not know them".

${ }^{63} \mathrm{http}: / / \mathrm{www}$.margaretthatcher.org/document/104431.

${ }^{64}$ Ibid.

${ }^{65}$ Ibid.

${ }^{66}$ Ibid. 
some generally accepted standards. Without them you have not got a society at all, you have purposeless anarchy." ${ }^{67}$

Again, we could take issue on questions of cause and effect when she claimed that:

"A healthy society is not created by its institutions, either. Great schools and universities do not make a great nation any more than great armies do. Only a great nation can create and involve great institutions - of learning, of healing, of scientific advance."68

Whichever comes first, however, she was clear that society exists.

Only after all that did she come in her 1980 conference speech to the famous expression: "To those waiting with bated breath for that favourite media catchphrase, the ' $U$ ' turn, I have only one thing to say. You turn if you want to. The lady's not for turning." ${ }^{69}$ So was she performing a U-turn when, in that Woman's Own interview in 1987, she later said, "There's no such thing as society"? ${ }^{70}$ The 2010 Conservative manifesto section entitled 'Change Society" was led by two telling comments that "There is such a thing as society' but "It's just not the same as the state". While understandably distancing themselves from her offending phrase, the Conservatives and all of us should look again at how she put things generally and what she really meant in this specific interview.

She liked the phrase "there is no such thing as", using it on many occasions. She said that "There is no such thing as public money", "There is no such thing as political murder, political bombing or political violence" and quoting Milton Friedman in light-hearted fashion at a fund-raising dinner, endorsed the saying that "there is no such thing as a free lunch". ${ }^{73}$ "There is no such thing as..." was a rhetorical device which expressed her personality, much like David Cameron has taken to "firing up" "74 this and that.

There were two relevant passages in her Woman's Own interview. She said that too many people had been given to understand that government would deal with their problems:

\footnotetext{
${ }^{67}$ Ibid.

68 Ibid.

${ }^{69}$ Ibid.

70 'Woman's Own interview' http://www.margaretthatcher.org/document/106689.

${ }^{71}$ Conservative manifesto 2010.

${ }^{72} \mathrm{http}$ ://www.margaretthatcher.org/document/105454.

${ }^{73} \mathrm{http}: / / w w w . m a r g a r e t t h a t c h e r . o r g / d o c u m e n t / 108381$

${ }^{74} \mathrm{~S}$ Lee, 'Firing up the Speech-writers, Firing up Society'

http://www.respublica.org.uk/item/Firing-up-the-speech-writers-firing-up-society where I also set out some of these extracts from Margaret Thatcher's speeches.
} 
"So they are casting their problems on society. And who is society? There is no such thing! There are individual men and women and there are families and no government can do anything except through people and people look to themselves first; it is our duty to look after ourselves and then also to look after our neighbour.,"75

You can almost hear her saying that. It was robust but it was not quite as harsh as it has been portrayed. Moreover, in the same interview, Margaret Thatcher paid particular attention to badly treated children and explained why she supported the National Society for the Prevention of Cruelty to Children as her long-standing "foremost" charity. She said that we should not be shying away from blaming the parents who have let children down and we should not excuse our own failure to help those children by foisting responsibility on society as a whole because,

"There is no such thing as society. There is a living tapestry of men and women and people and the beauty of that tapestry and the quality of our lives will depend upon how much each of us is prepared to take responsibility for ourselves and ... help by our own efforts those who are unfortunate. ${ }^{76}$

She explained in her memoirs that she meant in the interview that "society was not an abstraction, separate from the men and women who composed it, but a living structure of individuals, families, neighbours and voluntary associations". ${ }^{77}$ This is similar to the spirit of David Cameron's Big Society.

In an earlier interview, with the Spectator magazine in $1972,{ }^{78}$ there is a passage in which she uses 'society' in four successive sentences, followed swiftly by a single, albeit long, sentence in which she uses 'society' three times:

"Well, there are certain fundamental bases of our society here. The family is the basic unit of society. You have a rule of law that has also been quite basic to the freedoms of our society. Democracy is another essential feature of our society ..."79

\footnotetext{
75 'Woman's Own interview' (n 70).

${ }^{76}$ Ibid.

77 The Downing Street Years (n 13) 626; cf David Lodge, Ginger, You're Barmy (MacGibbon \& Kee 1962, Penguin 1984) 186 “... there was no such thing as society.”

${ }^{78} \mathrm{http}$ ://www.margaretthatcher.org/document/101821.

${ }^{79}$ Ibid.
} 
"... But those are all really quite basic things in our society and if you go on debunking them, go on debunking the rule of law, suggest that the family is not a good unit of society or try to challenge democracy by having pressure groups which have enormous power, and therefore try to wield power beyond their numbers against a will that has been democratically expressed in elections, then you are fundamentally overthrowing society to try to get your own views adopted."

In between these earlier and later affirmations of society, the central passage which deserves deeper analysis on another occasion is from her first party conference speech as leader of the Conservatives, in 1975, when she spoke of the significance of the rule of law for society:

"I come last to what many would put first. The Rule of Law. The first people to uphold the law should be governments. It is tragic that the Socialist Government, to its lasting shame, should have lost its nerve and shed its principles over the People's Republic of Clay Cross. And that a group of the Labour Party should have tried to turn the Shrewsbury pickets into martyrs. On both occasions the law was broken. On one, violence was done. No decent society can live like that. No responsible party should condone it. The first duty of Government is to uphold the law. If it tries to bob and weave and duck around that duty when it's inconvenient, if government does that, then so will the governed, and then nothing is safe - not home, not liberty, not life itself." ${ }^{\prime 1}$

Those who think that Margaret Thatcher lacked Lord Denning's sense of humour or his way with words might care to wake up and smell the bluebells. The perfume house of Penhaligon's created their most famous scent, Bluebell, in 1978, just in time for it to be worn by Margaret Thatcher when she won the 1979 general election to become our first female Prime Minister. She liked not just the smell but also the blue belle connotations. It has reportedly been a favourite fragrance also of Princess Diana, Kate Moss and Gwyneth Paltrow. Margaret Thatcher repeatedly punned her way through major speeches. For example, at the 1980 Lord Mayor's Banquet where the Lord Mayor was not only an accountant but a member of the Society of Glovers, Margaret Thatcher was able to point out that, "as you see, I too am a glover and proud of it. Yes, I have always liked gloves, though taking the gloves off tends to come with the job of Prime Minister." ${ }^{" 22}$

\footnotetext{
${ }^{80}$ Ibid.

${ }^{81} \mathrm{http} / / /$ www.margaretthatcher.org/document/102777.

${ }^{82} \mathrm{http}$ ://www.margaretthatcher.org/document/107380
} 
What else was in her blue handbag? Jim Zirin, an American lawyer, wrote in Forbes $^{83}$ about meeting Margaret Thatcher through the DeLorean case:

"I first met her when I took her deposition in London in 1992 in an action seeking roughly a billion dollars that Her Majesty's Government had brought in the federal court in New York against an accounting firm I represented. She was a witness ... 'No need to lecture me, Mr Zinn,' she said shaking her head, 'I am a lawyer by training, and I know all about your legal system.' She then withdrew from her large handbag a paperback copy of the Constitution. 'read it, Mr Zinn, it is inscribed to me by all nine justices of your Supreme Court. A magnificent declaration of liberty and human rights. I am never without it."

She still had that copy of the constitution in her handbag when he met her ten years later.

\section{LIFETIMES OF EXPERIENCE}

This country is about to embark on a serious period of remembrance of those who served in the First World War. ${ }^{84}$ Two of Lord Denning's brothers died in that Great War. Two others also served heroically but survived, as did he. The first to die was Jack, the eldest, who died in 1916 at the Somme. Two years later, when meant to be resting from the front line, Lord Denning rode twenty miles to find the grave. "There were two wild flowers. One red and one purple. I picked them and sent them home to father and mother." ${ }^{85} \mathrm{He}$ put up a new wooden cross made by his sappers, although now there is a stone memorial from the War Grave Commission, with the words "you may rest assured that I shall have done my duty." " That was from Jack's last letter home, which in turn was influenced by a letter he carried with him from Tom, ending with Horace's line that it is 'sweet and honourable to die for one's country'.

Words matter. So do images. If we see a part as the whole, that is a distorted impression of real life. The home of this law journal is at the University of Buckingham, an unusually independent and pioneering institution which was championed by Lord Denning and Baroness Thatcher so

\footnotetext{
83 http://www.forbes.com/sites/jameszirin/2013/04/08/margaret-thatcher-1925-2013a-personal-recollection/

84 https://www.gov.uk/government/speeches/speech-at-imperial-war-museum-onfirst-world-war-centenary-plans

${ }^{85}$ The Family Story (n 28) 48-9.

${ }^{86}$ Ibid, 49.
} 
it is appropriate that it should encourage the drawing of lessons from their lives and the sharing of them with successive generations of students, just as Lord Denning never tired of meeting students or of touring the world in the cause of freedom under the rule of law. ${ }^{87}$ While my original aim of exploring the thoughts and actions of Lord Denning and Margaret Thatcher on the rule of law and national security must await another opportunity, this precursor to that project has a more general application as a call to offer students a more rounded picture of leading figures in our public life. This is sorely needed. Alan Milburn, the former Labour MP and now the independent reviewer of social mobility appointed by the Conservative and Liberal Democrat coalition government, concluded in his 2012 report that "Across the professions as a whole, the glass ceiling has been scratched but not broken." ${ }^{88}$ At the end of the nineteenth century, Tom Denning was born over a draper's shop but went on to become Lord Denning, Master of the Rolls. Between the wars of the twentieth century, Margaret Thatcher was born over a grocer's shop but went on to become our first woman Prime Minister and then Baroness Thatcher. It would be difficult to find two people further apart politically than Sir Hebert Warren and Denis Pritt KC but we need to recover the spirit in which they helped the poor young Tom Denning to make his way in the law.

To return to Lord Quinton's intriguing observations about character and personality, this does not mean we need what he describes as "grimly factual biography" 89 but some attempt to capture the spirit of these leading lights in law and politics. Given the cricketing context of Lord Denning's judgment in Miller $v$ Jackson" and Margaret Thatcher's use of "a straight bat at the wicket" 91 to describe the approach of her former Deputy Prime Minister, William Whitelaw, the point could be put thus: if Margaret Thatcher was the Don Bradman ${ }^{92}$ of politics, a record-breaker, way ahead of everyone else, but not universally loved, then Lord Denning was the Keith Miller ${ }^{93}$ (no relation to the Miller of Miller $v$ Jackson). In a sequel to this article, I intend to consider some of Lord Denning's strokes of genius, some of his unplayable deliveries and some of Margaret Thatcher's relentless, Bradmanesque ability

${ }^{87}$ The business of judging (n 1) 412.

88 A Milburn, Fair Access to Professional Careers - A progress report by the Independent Reviewer on Social Mobility and Child Poverty (May 2012) 3:

https://www.gov.uk/government/uploads/system/uploads/attachment_data/file/61090/

IR_FairAccess_acc2.pdf.

${ }^{89}$ Quinton (n 10) 21.

${ }^{90}$ Miller (n 18).

${ }^{91} \mathrm{http}: / /$ www.margaretthatcher.org/document/107789.

92 N Cardus, 'D G Bradman', reproduced in A Ross (ed), The Penguin Cricketer's Companion (Penguin 1981, first published 1960) 301.

93 R Robinson, 'Touch of a Hero' (1951), reproduced in R Guha (editor), The Picador Book of Cricket (Picador 2001) 125. 
to concentrate and extraordinary will to win. Keith Miller was an all-rounder who played for Australia with Bradman and afterwards. Miller was a pilot in the Second World War, a striking figure, a formidably fast bowler, attacking batsman and talented fielder who was loved by the crowds for his energy and ability to surprise. The doyen of Australian cricket journalists, Ray Robinson, wrote of Keith Miller that, "His personality abolishes the boundary and brings the crowd into the game with him." ${ }^{.4}$ Lord Denning's character and personality drew students and the wider public into an appreciation of the zest he brought to the rule of law. In the words of Margaret Thatcher, writing in her own hand to George Thomas, the Speaker of the House of Commons, to thank him for the dinner he had hosted the previous evening in honour of the retiring Master of the Rolls, it was "a great privilege to hear Tom Denning speaking from a lifetime of experience". ${ }^{95}$ Having listened to Lord Denning in my own student days, this article is my attempt to go beyond boundaries in bringing later generations of students into the public square with some appreciation of that experience of Lord Denning and Baroness Thatcher.

\footnotetext{
${ }^{94}$ Ibid, 131.

${ }^{95} \mathrm{http} / / /$ www.margaretthatcher.org/document/123849.
} 